\title{
EARLY AMERICAN LABOR CASES
}

\author{
EDWIN E. WITTE
}

\section{EARLY CONSPIRACY CASES ${ }^{1}$}

Prior to the eighties there were but few reported decisions in cases which arose in connection with labor disputes in the United States. In consequence, all writers who discuss the beginnings of American labor law have devoted considerable attention to the early unreported cases in inferior courts which preceded Commonwealth v. Huitt in 1842.

These early unreported cases have usually ${ }^{3}$ been interpreted as reflecting "a spirit of medievalism with its antagonism to the working classes".4 It is commonly believed, as one writer puts it, that "in the early part of the nineteenth century, peaceable combinations of workingmen to better their conditions of employment were illegal both in England and the United States"; or, as expressed by another, that "combinations of worlmen to raise their wages, shorten hours and compel the employment of their own members were held unlawful conspiracies by the courts at common law and even under some of the statutes one hundred years ago". Commonwealth $v$. Hunt is usually regarded as the case which overthrew these archaic doctrines and which marl:s the beginning of the modern law of labor combinations, in which "the legal battle ground has shifted from a fight over the right of labor unions to exist to a contest as to what means may lawfully be used by labor organizations in the economic struggle over the price of labor":?'

This interpretation of the early American labor cases will not stand the test of an examination of the original sources. It is supported only by a few expressions of hostility to the newly founded labor unions by judges and prosecutors, which have been mistaken for established legal doctrines. It was never the law in the United States that labor unions are illegal per se, or that

1 All preserved records of these cases have been reprinted in Volumes III and IV of the Docunciztary History of Industrial Socicty, edited by John R. Commons and E. A. Gilmore. These records include the entire testimony and proceedings in several of these cases.

2 (1842, Miss.) 4 Miet. 111.

3 There are at least two writers who have not fallen into this error: Stimson, Handbook of Labor Law in the Crnited States (1896) and Martin, The MIodern Law of Labor Unions.

*Quotation from Groat, Attitude of American Courts in Labor Cascs (1911) 49.

5 Ely, Outlines of Economics, 472.

- Comment of Editor, 3 LAW AND Labor (1921) 236.

? Francis B. Sayre in Survey, Jan. 7, 1922, 558. 
all strikes are unlawful. The unreported cases of the early nineteenth century did not turn upon the legality of the unions per se, but on the methods which they employed to gain their ends. Nor were the views expressed in these early cases as to the methods which might lawfully be employed less liberal than those now generally held by the courts.

In one respect, indeed, these early cases differed radically from present-day legal actions in connection with labor disputes. This was that all these early cases, with one exception, involved criminal indictments for conspiracy, not injunctions or damage suits, as do most present-day cases. This is a difference, however, only in the character of the actions, not in underlying legal theories. As to these, there is little to distinguish the unreported cases of the early nineteenth century from the law to-day.

Only one of the legal theories which played a role in the early cases has been entirely abandoned. This was the theory that it is illegal for working-men to combine to raise wages. This doctrine had the support of numerous English precedents; but in this country it never attained the status of generally accepted law. In about one half of the early conspiracy cases, one of the counts in the indictment was to the effect that the defendants had combined to raise wages. In all of these cases, however, there were also charges of violence, picketing or closed shop rules and practices; and it was these charges which the prosecution emphasized, rather than the combination to raise wages.

In the earliest case, that of the Philadelphia cordwainers in 1806, the prosecution, indeed, made the point that a combination to raise wages is illegal at common law; but it also argued that the defendants were not indicted "for regulating their own individual wages, but for undertaking by a combination to regulate the price of labor of others as well as their own".8 Recorder Levy, however, was more positive, and squarely instructed the jury that a combination to raise wages was illegal. ${ }^{\circ}$

This case was followed by eighteen other prosecutions of working-men for conspiracy in the next three decades. In only one of them, however, did the court take the same view of the illegality of combinations to raise wages as did Recorder Levy.10 This was the New York case of People $v$. Fisher ${ }^{11}$ in 1835, in which Chief Justice Savage at some length developed the same thesis, although the case involved not merely a combination to

\footnotetext{
83 Documentary History of American Industrial Society, 68.

I I id. at 233.

10 In Commonwealth v. Carlisle (1821, Pa.) Bright. 36, which involved the legality of a combination of masters to decrease wages, Judge Gibson expressed the view that combinations to depress wages are criminal, if they seek to reduce wages "below what they would be, if there was no recurrence to artificial means by either side".
}

11 (1835, N. Y.) 14 Wend. 9. 
raise wages, but the threat of a strike to procure the discharge of non-union workmen.

This decision seems to have attracted little attention until the following year, when twenty tailors in New York City were heavily fined by Judge Edwards upon conviction for conspiracy. These tailors had been guilty of acts of intimidation and violence; but a great hue and cry was raised that they had been prosecuted because they had combined to raise their wages. An open air mass meeting, said to have been attended by 27,000 worling-men, was held a few days after the trial, at which Chief Justice Savage and Judge Edwards were burned in effigy and a correspondence committee was named to communicate with other trade unions about this case.12 Throughout the country, the Democratic newspapers sought to make political capital out of this case; and in Washington the mechanics in the Navy Yard staged a "burial of liberty", in which Judge Edwards figured as the executioner."13

A few months thereafter occurred the trial of the Hudson (N. Y.) shoemakers. The real issue in this case was the legality of the strike which the shoemakers' society had called to compel a master to pay a heavy fine for having employed a non-union workman. Counsel for the defense, however, found it advantageous to represent this case as a prosecution of working-men for combining to raise their wages. The outcome was "that the court charged in favor of convicting them, but they were acquitted by the jury, notwithstanding".."

After the acquital of the Hudson shoemakers, the doctrine that a combination to raise wages is illegal was allowed to die by common consent. No leading case was required for its overthrow. America was poor soil for this transplanted doctrine, and it could not withstand the hearty blasts of the Jaclisonian demoeracy. In fact, it drooped and withered before it ever tools root. Not one of the early conspiracy cases turned exclusively, nor even principally, upon this theory. In all of them the prosecution centered its case upon the coercive practices of the journeymen's societies; and Recorder Levy and Chief Justice Savage were the only American judges who ever held that a combination to raise wages is illegal.

The defendants in all of the cases prior to Commonwealth 2 . Hunt used means to effect their ends which are generally regarded as unlawful even now. In nearly all of these cases the star witnesses for the prosecution were non-union worlmen who had lost their jobs because the indicted union members refused to work with them. Some cases involved even more doubtful practices. In the Buffalo tailors' case in 1824 the defendants sent

\footnotetext{
12: New York Journal of Conmerce, June 18, 1836; New Forls Evening Post, July 14, 1836.

15 Hartford Times, June 22 and 23, 1836; Washingtonian, June 23, 1836

14 Hartford Times, July 13, 1836.
} 
a list of "black legs" to unions throughout the country to prevent the hated non-unionists from getting work anywhere. The Baltimore weavers' case in 1829 arose because the defendants had taken an oath that none of them would work for a certain master for two years; and, as has been noted, the Hudson shoemakers in 1826 went on strike to compel a master to pay a heavy fine for employing a non-union workman. Yet in none of these cases nor in any other conspiracy cases prior to the Civil War was a single workman sentenced to jail, and only in the New York tailors' case were heavy fines imposed; while a considerable number of these cases resulted in acquittals.

In several of these early conspiracy cases the prosecution or the court, or both, stated that it was the methods which the defendants had used which rendered their combination illegal; but it was not until Commonwealth $v$. Hunt ${ }^{15}$ that the distinction vaguely hinted at in these early cases, between the legality of the combination per se and the methods which it employs was clearly expressed. This famous case, like many of the cases which preceded it, involved a strike to procure the discharge of a nonunion workman. Today, such a strike is illegal in Massachusetts $;^{10}$ but in this case in 1842 the Supreme Court of that state in a unanimous decision written by Chief Justice Shaw held the conduct of these strikers to have been entirely lawful.

This decision, however, did not, as some writers have stated, mark the end of the application of the conspiracy doctrine to labor combinations. Even today this doctrine is the most important of all legal theories which figure in labor cases. Far from repudiating this doctrine, Commonwealth $v$. Hunt expressed it in the form in which it usually has been expressed since, namely, that the legality of a combination depends upon the purposes sought to be accomplished and the means used to effect these ends.

\section{CONSPIRACY CASES AFTER COMMONWEALTH V. HUNT ${ }^{17}$}

Except for its influence upon the form of the statement of the conspiracy doctrine, Commonwealth v. Hunt seems to have had comparatively little effect upon the development of the law of

\footnotetext{
15 Supra note 2.

16 Plant v. Woods (1900) 176 Mass. 492, 57 N. E. 1011; Bausch Machine Tool Co. v. Hill (1918) 231 Mass. 30,120 N. E. 188, and numerous other cases.

17 The conspiracy cases later than Commonwealth $v$. Hunt have heretofore almost entirely escaped notice. Even in the two volume Labor History of the Unitdd States by Dr. John R. Commons and his associates, which devotes twenty-five pages to the cases prior to 1842, only one of tho later cases is mentioned,-the Siney trial in 1875, which is noted briefly in a foot note.

The reason why the later cases have been overlooked, is that the only
} 
labor combinations in this country. In the next twenty years, indeed, only three conspiracy cases are known to have occurred in connection with labor disputes ; ${ }^{18}$ but that there were not more such cases is readily explained by the almost complete absence of strikes during this period. With the general revival of trade unionism in the closing years of the Civil War, conspiracy cases once more became of frequent occurrence. From 1863 to 1880 there were at least seven conspiracy cases in Pennsylvania, five in New York, three in New Jersey and one each in Connecticut, Mlinois and Missouri.10

These prosecutions led the labor organizations of this period to demand "the repeal of the conspiracy laws",; by which was meant the enactment of legislation to nullify the conspiracy doe-

information about then consists of brief accounts in the newspapers and in the reports of labor bureaus. Some of these accounts may not be accurate in all respects; but collectively they establish that numerous criminal prosecutions for conspiracy occurred in connection with lator disputes after Commonwealth $v$. Hunt. In all probability there vere many more such cases than are noted in this article.

18 These cases were the Lehigh boatmen's case in 1843 (Philadelphia Public Ledger, Sept. 2, 1843), the Philadelphia compositors' case in 1354 (Philadelphia North American and U. S. Gazette; Pennsylvania Bureau of Industrial Statistics, Report, 1880-81, 276) and the Glassboro (N. J.) glassblowers' case in 1859. (New Jersey Bureau of Labor Report, 1837, 1046).

19 In addition to the cases discussed in this article the following conspiracy cases growing out of labor disputes occurred between 1803 and 1880: Pennsylvania-Hunters' Point Railroad car-drivers, 1869 (American Workman, Aug. 7, 1869) ; Erie printers, 1870 (Typographical Union Convention Proceedings, 1870) ; Pittsburgh printers, 1873 (Pittsburgh Commercial, Nov. 21 and 29, 1873; Pittsburgh National Labor Tribune, March 14, 1874); New York-Keyes case, 1863 (New York Sun, April 10 and 23, 1863); New York bricklayers, 1868 (Workingmen's Advoeate, Dec. 9, 1868) ; Morrisania bricklayers and Kingston cigar malkers, 1868 (National Labor Union Convention Proceedings, 1868, at 12); New Yorls Crispins, 1876 (New York Herald, March 10 and 30, April 1, 1876); Connecticut-New Haven Printers, 1871 (New Haven Journeyman Printer, June 20, July 6 and 11, 1871); New Jersey-State v. Donaldson (1867) 23 N. J. I. 151; Newark bricklayers, 1868; Paterson molders, 1868 (Molders' Journal, '1868, at 40); Illinois-Chicago molders, 1873 (Worlingmen's Advocate, April 5, 1873) ; Missouri-Vulcan Iron Works, St. Louis, 1879 (Carpenter, July 1882).

20 The "conspiracy laws" of which labor complained were principally prosecutions at common law or under general statutes defining conspiracy, not statutes specifically directed against labor combinations. Exceptions were the so-called "La Salle Black Law" enacted by the Illinois legislature of 1863 , which prohibited combining to prevent worlsmen from worling or to interfere with the lawful use and management of property "by threats or other means", and a similar statute enacted by Connecticut in 1864, which was considerably toned down in 1875. Later, two states-Connecticut in 1877 and Mraine in 1880-enacted statutes penalizing conspiracies to interfere with the operation of railroad, gas and telegraph companies. 
trine of the common law. Such legislation was won in Pennsylvania, New York, New Jersey and Maryland, and in part, also in Tllinois. ${ }^{21}$ It proved a great disappointment in operation, however, actually making practically no change in the law, and failing to end prosecutions for conspiracy premised upon participation in strikes.

The fight against the "conspiracy laws" was carried on most vigorously in Pennsylvania, because it was in that state that the largest number and most important of the conspiracy trials occurred. This state as early as 1869 passed a law declaring trade unions to be legal if formed for "mutual aid, benefit and protection". That this law did not go far enough, however, the unions discovered a few months after its passage, when the members of a mine committee at Pottsville were found guilty of conspiracy, sentenced to jail for thirty days and fined heavily in addition because they had presented the demands of the union to the colliery owners. ${ }^{22}$ Then followed renewed efforts to gain relief through legislation, until in $\mathbf{1 8 7 2}$ the labor papers again acclaimed the "repeal of the conspiracy laws", upon passage of a new act which provided that working-men might singly or collectively refuse to work for any employer, but also that this should not be construed as legalizing attempts to hinder others from working.

Under this statute arose two conspiracy trials, which in their consequences were much more important to the labor movement than all of the cases which preceded Commonwealth v. Hunt.as These cases grew out of a coal miners' strike in Clearfield County in (1875, which was conducted by the National Miners' Association, then numerically the largest American trade union. First fifty-six of the strikers were tried upon a charge of "conspiracy" and thirty-six of them were convicted and sentenced to jail, although they seem to have been guilty of no more serious offense than what would now be called "peaceful picketing". Then Siney, the president of the National Miners' Association, and Parks, one of the organizers, were tried upon the same charge. After a long trial, in which the union officials were defended by United States Senator Carpenter of Wisconsin, Siney was acquitted, but Parks was convicted. These prosecutions all but bankrupted and

\footnotetext{
21 Pennsylvania-Acts of May 8, 1869, June 14, 1872, April 20, 1876 and June 19, 1891. New York-Laws 1870, ch. 18; Penal Code, 1881, sec. 170; Laws, 1882, ch. 384. New Jersey-Laws 1877, at 142; New Jersey-Laws 1883, at 36. Maryland-Acts 1884, ch. 266. Illinois-Laws 1873, at 76.

22 Commonwealth v. Curren, 3 Pitts. 143; Pennsylvania Bureau of Labor Statistics Report, 1872-3, at 338-347.

${ }_{23}$ The facts as to these cases here given are based upon the accounts in Pennsylvania Bureau of Labor Statistics Report, 1880-81, 315; Workingmen's Advocate, Oct. 9, 1875; Pittsburgh National Labor Tribune, Oct. 9, 1875.
} 
disrupted the National Mliners' Association, which never again developed much strength.

These cases led in the next year to another liberalization of the Pennsylvania conspiracy law, through amendment providing that only "force, threat, or menace of harm to person or property" should be considered illegal. Even thereafter, however, Pennsylvania had numerous conspiracy cases, at least fourteen oceurring in that state during the decade of the eighties. Of these the most important was the prosecution of D. R. Jones and Hugh Anderson, officers of the Miners' Association, because they had sought to organize the employes of the Waverly Coal Co. in Westmoreland County. ${ }^{21}$ These union officials were convicted in 1881, fined $\$ 100$ each and sentenced to imprisonment for one day, and then appealed to the Pennsylvania Supreme Court on the ground that the 1876 statute had legalized their conduct. This court, however, dismissed the appeal without delivering an opinion. In another case in the same year a number of the members of the Knights of Labor in Somerset County were prosecuted for conspiracy on the theory that mere membership in this, then secret, society constituted a conspiracy.25 According to T. V. Powderly, long the Grand MIaster of the Knights of Labor, it was this ease which led this powerful labor organization to abandon its secret ritual. Still another important case was that of twenty miners, members of the Knights of Labor, who in January 1887 were sentenced to four months in jail upon conviction for conspiracy, but pardoned by the Governor of Pennsylvania after serving half of their sentence.".

In other states the conspiracy cases in connection with labor disputes were less numerous and less dramatic, but by no means infrequent or unimportant. As already noted, there were at least eleven conspiracy cases in connection with labor disputes elsewhere than in Pennsylvania in the period between 1863 and 1880. There were still more such cases in the eighties, $2=$ particularly during the years 1885 to 1887 , when the general public became greatly alarmed about the many strikes and boycotts which were

\footnotetext{
24 Pennsylvania Bureau of Labor Statistics Report, 1880-81, 379-380; Pittsburgh Dispatch, Oct. 24, 1881.

${ }^{25}$ Powderly, Thirty Iears of Labor, 2.

26 Swinton's Paper, March 27, 1887.

$2 \pi$ Some of these conspiracy cases of the eighties are reported, including Commonwealth ex rel. Vallette v. Sheriff (1S81, Pa.) 15 Phil. Rep. 393; State v. Stewart (1887) 59 Vt. 273, 9 Atl. 559; State v. Glidden (1887) 55 Conn. 47, 8 Atl. 890; Crump v. Commonzealth (188s) 84 Va. 927, 6 S. E. 620; Callan v. Wilson (1888) 127 U. S. 540, 8 Sup. Ct. 1301; Pcople ez rel. Gill v. Walsh (1888) 110 N. Y. 633, 17 N. E. 871. The great majority of the conspiracy cases of the eighties, as earlier, however, are unreported and can be traced only through the newspapers and through the reports of state labor departments.
} 
then occurring and the violence which characterized some of these disputes.

Since then comparatively few criminal prosecutions for conspiracy have grown out of labor disputes, except under statutes prohibiting combinations to commit specific offenses such.as interference with the mails or with interstate commerce. ${ }^{2 s}$ This development, however, was due neither to court decisions overthrowing old doctrines nor to legislation repealing the "conspiracy laws". If anything, court decisions of the later eighties and early nineties were less favorable to labor than the decisions of an earlier date; certainly, none of them were as favorable as Commonvealth $v$. Hunt. As for legislation, instead of laws to afford labor relief from the conspiracy doctrine, several states during this period enacted statutes specifically directed against labor combinations. ${ }^{20}$

\section{EARLY INJUNCTIONS}

Criminal prosecutions for conspiracy became infrequent after the "eighties" not because of any changes in the substantive law, but solely because injunctions became the usual form of action in legal controversies growing out of labor disputes.

Precisely when the first injunction was issued in the United States is not known, but it was several years before Sherry $v$. Perkins ${ }^{30}$ and United States $v$. Debs ${ }^{31}$ which are usually cited as the first labor injunctions. The earliest case in which an injunction was sought but not granted, was Johnson Harvester Co. $v$. Meinhardt, ${ }^{32}$ which arose at Brocksport, near Rochester, New York, in 1880. In his Thirty Years of Labor, ${ }^{33}$ T. V. Powderly states that injunctions were actually issued in 1883 at Baltimore, Md. and at Kent, Ohio, against glass workers belonging to the Knights of Labor Assembly No. 300, to prevent their efforts to induce contract laborers from Europe to leave the manufacturers who had imported them. Certain it is that an injunction was issued during a coal miners' strike on Dec. 8,1884 by Circuit Judge D. D. Miracle of Boone County, Iowa, in the case of Key-

\footnotetext{
${ }^{28} \mathrm{~A}$ few cases, however, have occurred since 1890 which are in all respects similar to the earlier conspiracy cases. Most of these cases are unreported, but at least two of them are reported: State v. Dyer (1895) 67 Vt. 690, 32 Atl. 814 and State v. Stockford (1904) 77 Conn. 227, 58 Atl. 769.

${ }^{29}$ Illinois, Laws 1887, 168 (repealed, Laws 1891, 100) and Laws 1887, 167; Wisconsin, Laws 1887, ch. 287; Minnesota, Laws 1886, ch. 139.

30 (1888) 147 Mass. 212,17 N. E. 307.

31 (1894, C. C. N. D. IIl.) 64 Fed. 724.

$22(1880, N$. Y.) 60 How. Pr. 168. In the Iron Molder's Journal, May 10, 1881 , it is stated that a temporary injunction was allowed against the strikers, which the court refused to make permanent after a hearing. From the reported case, however, it would seem that no injunction was ever issued.
}

33 At $442-443$. 
stone Coal Co. v. Dovis. ${ }^{34}$ A year later S. A. Brewster, publisher of the Advertiser.at Creston, Iowa, secured an injunction against the circulation of a sheet giving the names of advertisers in his columns and urging that they be boycotted by friends of labor.

It was not until 1886, however, that there were any large number of labor injunctions. In that year at least five injunetions were issued in connection with labor disputes in Chicago, one of them a federal injunction allowed to the Lake Shore Railroad by Judge Gresham. ${ }^{36}$ A yet larger number of injunctions were secured by the MIissouri Pacific in the Southwest strike of this year. In Missouri alone there appear to have been eight distinct injunctions, and others were taken out in Arkansas, Kansas and Texas, including two federal injunctions in Kansas.: In the same strike another federal injunction was issued to the International \& Great Northern R. R. Co. in Texas. ${ }^{33}$ During this year, also, an injunction was issued against a boycott at Richmond, Va., and another injunction in New York City against the enforcement of a rule of the musicians' union which prohibited members from playing with non-members. ${ }^{30}$ In this year, also, the first notice was taken of labor injunctions in the legal periodicals.

It was not until some years later, however, that the modern well-rounded theory in justification of the issuance of injunctions in labor disputes was developed. This theory links injunetions in labor disputes with the protection of property from irreparable injury. This has always been the principal reason for the intervention of equity; but it was invoked as a justification for the issuance of injunctions in labor disputes in but few cases prior to 1895. The explanation of this fact is that the property which is protected by injunctions is not merely the physical property of

2.1 The complete text of this injunction is given in the Report of the Iowa Bureau of Labor Statistics for 1885, at 155.

${ }^{35}$ Bradstreets, Dec. 19, 1885, at 396.

${ }^{30}$ These injunctions were: Lake Shore \& Michigan So. R. R. v. Stuitchmen, Judge Gresham (text in Indianapolis Journal, June 29, 1856); Bruschke v. Fumiture Worliers' Union No. 1, 18 CHr. L. NEws, 306; Lalie Shore \& Afichigan So. $R . R$. v. O'ficefe, Judge Garnett (Chicngo Times, April 23, 1886); an injunction secured by the Calumet Iron \& Stcel Co. (Chicago Times, MIay 8, 1886); and an injunction secured by the Northwestern Fertilizer Co. (Chicago Times, May 30, 1886).

${ }_{37}$ "Official History of the Great Strilie of 1886 " in the Missouri Bureau of Labor Report for 1887, 28-35; Chicago Times, MIarch 21, 1886.

is Chicago Times, Miarch 17, 1886.

$39 \mathrm{New}$ York Bureau of Labor Report, 18s6, at 806; 21 Aar L. REv. 530 .

10 There is a suggestion of the modern theory in Jolmson Harecoter Co. v. Meinhardt, supra note 32 , at 171, in which it was rejected, and there are fairly clear statements of this theory in Binschlie v. Fumiture Mralkcrs' Union, supra note 36; Brace v. Evaizs (1Ss8) 3 Ry. \& Corp. Law Journal, 560 and, above all, in Barr v. Esser Trades Council (1894) 53 N. J. Eq. 101, 30 Atl. 885. 
the complainants, ${ }^{41}$ but also their right of free access to the labor and commodity markets and their established relations with customers and employes, which in the "eighties" were not yet generally thought of as property rights.

Two theories, which now are but seldom invoked in labor cases, were employed at this time to justify the issuance of injunctions in labor disputes. One of these was the ancient doctrine that equity will intervene to protect the public from nuisances. ${ }^{42}$ The other, and much more important in this connection, was the theory that the courts must protect public carriers in the discharge of their duty to render service to the public at all times.

As early as the great railroad strike of 1877 the courts extended their protection over the large part of the railroad mileage of the country which was then in the hands of receivers. This was done through orders directing the marshals to advise the strikers and the public generally that interference with the operation of these railroads would be punished as contempt of court. ${ }^{43}$ These orders were much like present-day injunctions, except that they were not directed against named individuals and that they included an instruction to the marshals to employ enough special deputies, at the receivers' expense, adequately to protect the property.

Similar orders in receivership cases were issued in the Wabash strikes of 1885 and in the Southwest strike of 1886. In this last strike, as has been noted, the courts also issued a considerable number of injunctions to the Missouri Pacific, a railroad not in the hands of receivers; and a few weeks later Judge Gresham issued his injunction for the protection of the solvent Lake Shore line. These injunctions were premised upon the theory that since public carriers are in duty bound to serve the public at all times, it is the function of the courts to protect them against all interference which would prevent them from fulfilling this obligation. Four years earlier, during the freight handlers'

11 In a few of the early injunction cases the courts apparently sought only to protect the physical property of the complainants. See Keystono Coal Co. v. Davis, Boone County, Iowa, Dec. 8, 1884 (Report of the Iowa Bureau of Labor Statistics, 1885, at 155), and New York, L. E. \& W. R. R. v. Wenger (1886, Ohio) 17 Wr. L. BuLL. 306.

42 This theory was invoked in MIurdock v. Walker (1893) $152 \mathrm{~Pa} .595$, 25 Atl. 492; Coeur d'Alene Mining Co. v. Miners' Union (1892, C. C. D. Idaho) 51 Fed. 260; and Elder v. Whitesides (1895, C. C. E. D. La.) 72 Fed. 724.

43 Out of these orders to marshals to protect the property of railroads in the hands of receivers and to warn strikers against interference issued during the great strike of 1877 arose the reported cases Secor v. Toledo, Peoria \& Warsaw R. R. (1877, C. C. N. D. Ill.) 7 Biss. 513 and King v. Ohio \& Mississippi R. R. (1877, C. C. E. D. Ind.) Fed. Cas. No. 7800 . In addition there were in other districts, as disclosed by contemporary newspaper accounts, about a half dozen similar orders which did not figure in any reported cases. 
strike of 1882, the attorney general of New York had sought a writ of mandamus to compel the railroads involved promptly to handle all freight offered to them by shippers."s At that time a New York Supreme Court justice held that equity will not intervene to compel public carriers to fulfill their duty to serve the public. In these 1886 cases, however, this obligation was made the basis for injunctions to protect the railroads from interference by strikers. In the next year was passed the Interstate Commerce Act, and in 1890 the Sherman Anti-Trust Act. These acts were interpreted in numerous cases in inferior federal courts as expressing in statutory form the right of equity courts to intervene in the interests of the general publie to protect public carriers in the operation of their properties, and furnished the justification for a majority of all injunctions issued in labor cases in the later eighties and early nineties.

During this period many orders in receivership cases like these first used in the railroad strike of 1877 were issued, in addition to the numerous injunctions. In fact, these orders in receivership cases were popularly called injunctions, ${ }^{\text {s5 }}$ although usually directed to the marshals and mentioning none of the striliers by name. Except for this difference in form, however, there was little to distinguish the early injunctions from the directions to marshals in receivership cases. In many, if not nearly all early injunction cases the marshals employed, often under the specific direction of the courts, special deputies at the complainant's expense to protect their property. As this practice clearly indicates, injunctions were generally thought of at this time as having the same purpose as receivership orders, namely, to place the property of public carriers under the protection of the equity courts.

With such a theory of injunctions, it is not surprising that their use in labor disputes provoked a great deal of protest on the ground that equity was being employed to enforce the criminal law and, thus operated, to deny persons accused of crimes the right of trial by jury. This was the first line of attack upon injunctions in labor cases and had the support of many eminent crities. ${ }^{16}$

\footnotetext{
14 A full account of the proceedings in this case and of the decision of the court is given in the New York Daily Tribune, July 18, 19, 20 and 29 , 1882.

15 An illustration of this confusion is afforded by the well-lnown "injunction" of Judge Jenkins in the case of Farmers Loon \& Trust Co. $v$. Northern Pacific $R$. $R$., which was modified by the Circuit Court of Appeals in Arthur v. Oakes (1894, C. C. A. 7th) 63 Fed. 310. This was in fact a receivership order, not an injunction of the modern bind.

46 Among the persons who during the "nineties" criticized the use made of injunctions on this score were Dean William Draper Lewis, S. S. Gregory, later president of the American Bar Association, Charles C. Allen, F. J. Stimson, Chief Justice MrCabe of the Supreme Court of Indiana,
} 
But even before these critics became vocal, the courts were gradually developing the present-day theory, which makes the object sought by injunctions not the enforcement of the criminal law but the protection of property from irreparable injury. This shift occurred through the recognition of the right of free access to the labor and commodity markets, often called "the right to do business", as property, just as deserving of the protection of the courts as "tangible" property. Isolated cases holding such a definition of property are very old; but it was not until about the time when injunctions were first used in labor disputes that this conception became general. Such extension of the concept of property occurred independently of the use of injunctions in labor disputes, and merely refiected the economic fact that the right to do business and established relationships had become in this industrial age the most valuable of all business assets. In fact, this modern definition of what constitutes property was not generally adopted in labor injunction cases until more than ten years after the first labor injunction was issued.

The present-day justification of the use of injunctions in labor disputes came into general acceptance after the decision of the United States Supreme Court in the Debs case in 1895.47 In this famous case the lower court premised the injunction which it allowed to the Attorney General of the United States upon the Sherman Anti-Trust Act. The Supreme Court, however, refused to pass upon the question whether injunctions can be used to enforce this penal statute, and found the justification for the issuance of the injunction in the ancient doctrine that equity will protect property from irreparable injury.

\section{CONCLUSION}

The development of the law of labor combinations in the United States has been very different from that of England. In England labor unions were in the early nineteenth century deemed to be illegal, even criminal combinations; and every act in furtherance of their objects was an indictable offense. By statutory enactments, culminating in the Trade Union Act of 1871, the Conspiracy and Protection of Property Act of 1875 and the Trades Disputes Act of 1906, however, labor unions have now not only been legalized, but their acts have been exempted entirely from the law of conspiracy; and they have even been exempted from all liability for tortious acts committed in their behalf.

In the United States, it was never generally accepted as law that labor unions are unlawful, although a few attempts were made to apply what was called the "common law" rule of the

U. S. Circuit Judge Caldwell, and Chief Justice Tuley of the Illinois Ap. pellate Court.

¿7 Debs v. United States (1895) 158 U. S. 564, 15 Sup. Ct. 900. 
illegality of all combinations to raise wages. From the outset, the courts of this country generally accorded worling-men the right to organize for their mutual economic betterment, and scrutinized only the measures they adopted to gain their ends. But while labor unions never were unlawful in this country, as they were at one time in England, they, also, have never gained the same freedom of action which has now been accorded to labor by acts of Parliament. The decisions of the courts today upon what conduct in the furtherance of the objects of labor unions is lawful, are not one whit more liberal than the doetrines announced in the earliest cases; and the statutes enacted have been practically without effect. As regards substantive rights, the law of labor combinations in the United States has remained unchanged, except as to details, throughout its entire history.

The fundamentally important changes which have oceurred, relate to remedies, not to substantive rights. For more than three quarters of a century after the first American labor case, practically the only remedy was a criminal prosecution for conspiracy. Then in the "eighties" was developed the injunction, and within the last fifteen years the damage suit. From a practical point of view it is the stages in the development of these remedies which constitute the most important chapters in the history of the American law of labor combinations. 